\title{
Humeral shaft hypertrophic non-union mimicking malignant lesion
}

\author{
Hosam E Matar, Karthikeyan P Iyengar, Eugene M Toh
}

Department of Trauma \& Orthopaedics, Southport \& Ormskirk University Hospital NHS Trust, Southport, UK

\section{Correspondence to}

Hosam E Matar,

hematar@doctors.org.uk

\section{DESCRIPTION}

Isolated humeral shaft fractures account for 3-5\% of adult fractures, and non-operative management is the mainstay of the treatment with overall good results. Humeral functional bracing is commonly used to provide mechanical stability aiding fracture healing. ${ }^{1}$ However, non-union is a recognised complication of these fractures with an estimated prevalence of $5.5 \% .^{2}$ Non-union occurs when a fracture has failed to heal in the expected time; hypertrophic non-union is associated with adequate healing response and good vascularity but lacks adequate immobilisation or stability to progress to union. $^{2} 3$

We present an interesting case of hypertrophic non-union of humeral shaft fracture in a 63-yearold woman. She is fully independent, medically fit and well, right-handed and a non-smoker presented to minor injuries unit with a painful left shoulder following a simple fall. On examination, she had mild tenderness over her acromioclavicular joint with a good range of motion in her shoulder and had an intact neurovascular status. However, while examining her arm, a completely asymptomatic mass was readily palpable over the middle left humerus with a detectable motion in the midhumerus. On further questioning, it appeared that she was involved in a road traffic accident and sustained a closed humeral shaft fracture 17 years ago which was treated non-operatively.

Plain radiographs (figure 1) demonstrated a suspicious solitary diaphyseal humeral lesion, sparing the cortices and surrounding soft tissues with an abundance of bone formation. However, the diagnosis of hypertrophic non-union is confirmed on MRI (figure 2). She is fully functional and asymptomatic and no further management is required.

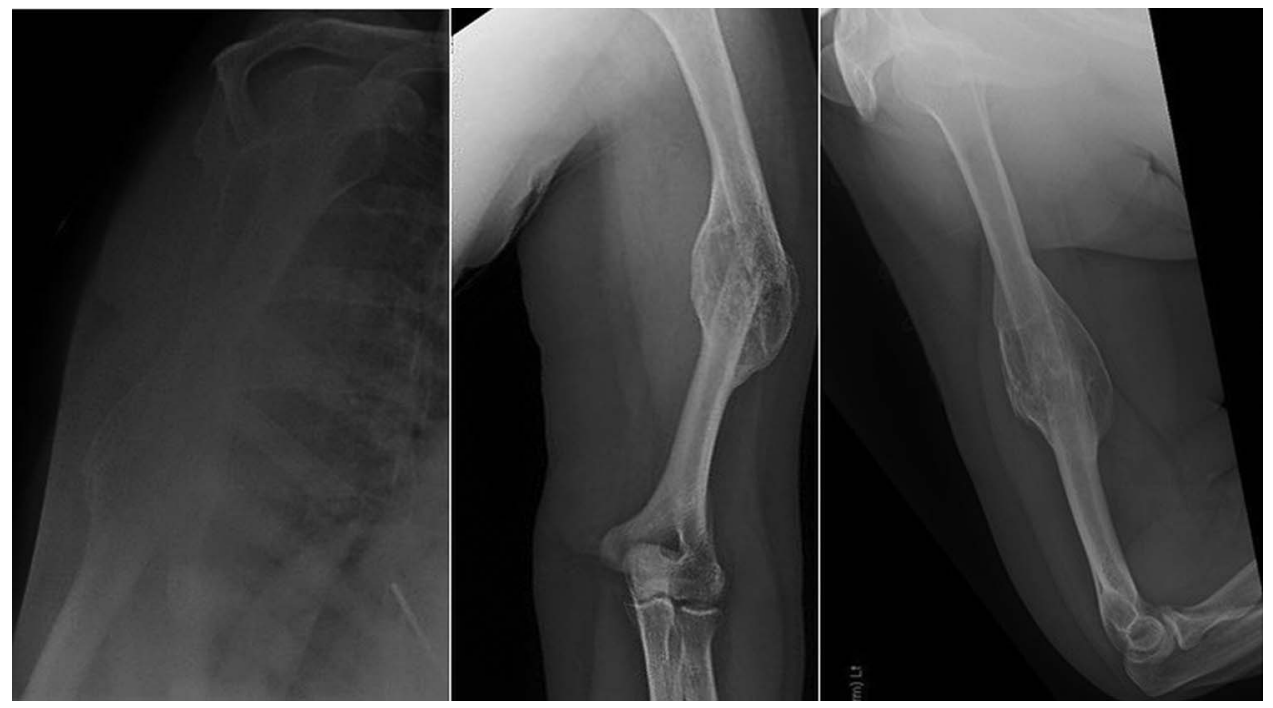

Figure 1 Anteroposterior and lateral plain radiographs of left humerus demonstrating a hypertrophic non-union of humeral shaft fracture. 
Figure 2 Coronal and sagittal MRIs demonstrating hypertrophic non-union of humeral shaft fracture.

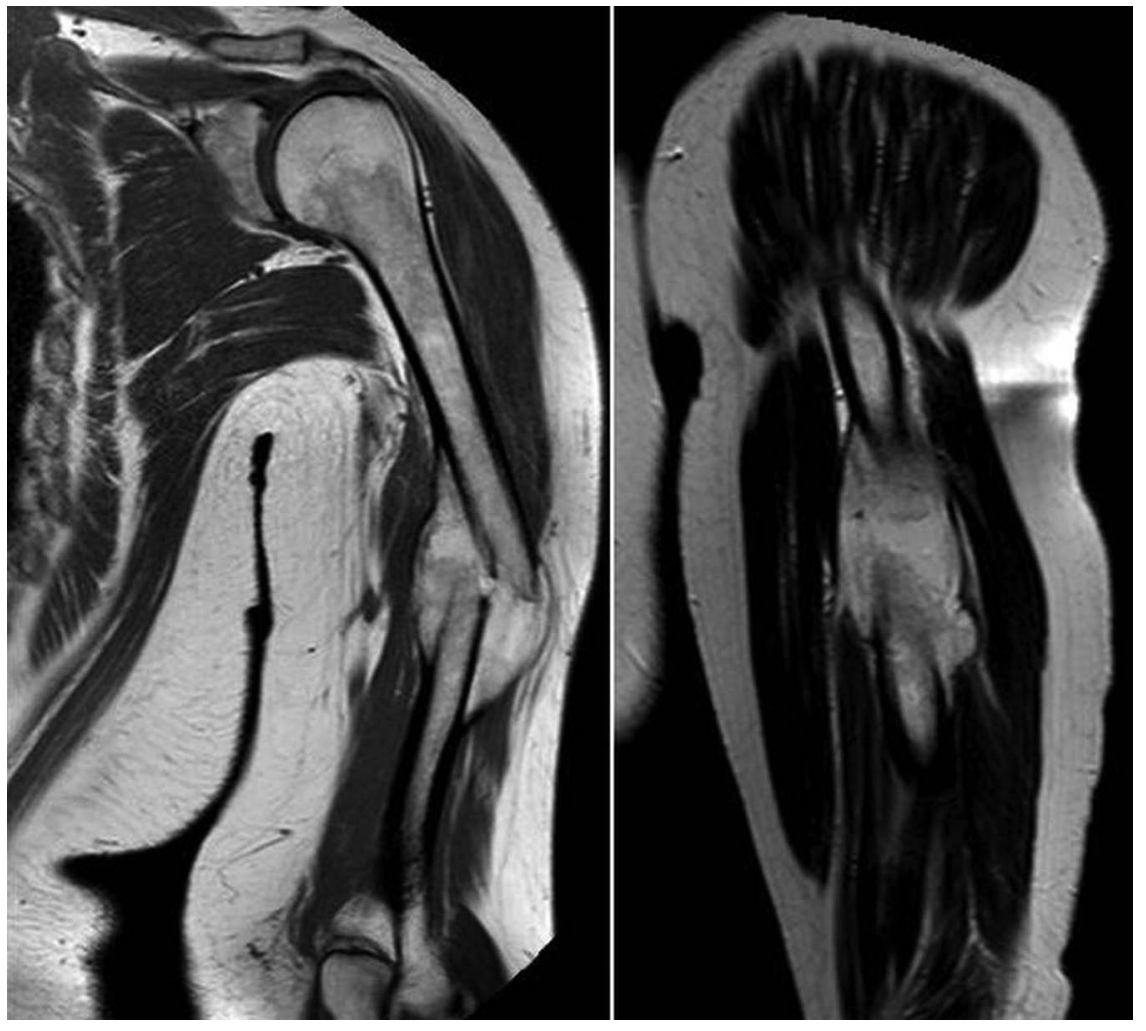

\section{Learning points}

-When performing orthopaedic examination, always consider examining the joint above and below as appropriate.

- Humeral shaft fractures are common orthopaedic injuries that can often be managed non-operatively with high union rates and generally good functional outcomes.

- Radiological appearance of fracture non-union can mimic a malignant lesion, and if so further investigations are required.
Acknowledgements The author would like to thank 'Greater Manchester \& Oswestry Bone and Soft Tissue Tumour Service' MDT.

\section{Competing interests None.}

Patient consent Obtained.

Provenance and peer review Not commissioned; externally peer reviewed.

\section{REFERENCES}

1 Spiguel AR, Steffner RJ. Humeral shaft fractures. Curr Rev Musculoskelet Med 2012;5:177-83.

2 Cadet ER, Yin B, Schulz B, et al. Proximal humerus and humeral shaft nonunions. J Am Acad Orthop Surg 2013;21:538-47.

3 Walker M, Palumbo B, Badman B, et al. shaft fractures: a review. J Shoulder Elbow Surg 2011:20:833-44.

Copyright 2013 BMJ Publishing Group. All rights reserved. For permission to reuse any of this content visit http://group.bmj.com/group/rights-licensing/permissions.

BMJ Case Report Fellows may re-use this article for personal use and teaching without any further permission.

Become a Fellow of BMJ Case Reports today and you can:

- Submit as many cases as you like

- Enjoy fast sympathetic peer review and rapid publication of accepted articles

- Access all the published articles

- Re-use any of the published material for personal use and teaching without further permission

For information on Institutional Fellowships contact consortiasales@bmjgroup.com

Visit casereports.bmj.com for more articles like this and to become a Fellow 